\title{
Land subsidence/rebound change after Hazelwood mine rehabilitation
}

\author{
EP Waghorne GHD Pty Ltd, Australia \\ MM Disfani The University of Melbourne, Australia
}

\begin{abstract}
As the power stations in the Latrobe Valley, Victoria, reach the end of their economic life, mine closures are anticipated. The closure of ENGIE's Hazelwood Power Station and associated mine has already occurred and mine rehabilitation and closure planning are well under way.

During mining, pumping from deep, high pressure aquifers was required to reduce mine stability risks. This pumping, combined with water extraction (by others) for domestic supply and agricultural use, has lowered aquifer water pressures across the region. As a result, there has been gradual land subsidence of 0.3 to $0.5 \mathrm{~m}$ across the region, with 1 to $2 \mathrm{~m}$ close to the mines.

The Hazelwood mine rehabilitation plan includes the construction of an internal lake to balance uplift forces from the aquifers, allowing aquifer pumping at the mine to cease. Over the following decades, the aquifer pressure will recover, and a reduction of in situ effective stresses will occur so that compressible sediments in the strata will swell. Whilst future changes to the land surface are expected to occur slowly it will be important to understand the magnitude of the change and to assess any impacts on community infrastructure.

As there had been limited investigations into the swell properties of the sediments in the Latrobe Valley, an investigation was commenced at the University of Melbourne on the thick compressible coal seams and clay sediments found near the mine. The effect during loading, of creep and chemical/micro-structure changes on the swell properties of brown coal was also studied.

A background of aquifer pressure changes and subsidence in the Latrobe Valley over the last 60 years is provided, with recent test results and discussion of their significance on land subsidence and rebound prediction over the next 50 to 100 years.
\end{abstract}

Keywords: mine rehabilitation, mine closure, subsidence, rebound, aquifer, strata testing.

\section{Introduction to regional land surface movements}

Coal was mined at ENGIE's Hazelwood mine from the 1950s supplying briquette factories for solid fuel supply, and power stations providing about $25 \%$ of Victorian power needs. With an annual brown coal production of about $18 \mathrm{Mtpa}$, Hazelwood has been one of Australia's largest open cut coal producers (Waghorne 2009). This paper outlines past land subsidence and discusses likely future changes after mine closure.

During mining, regional ground movements were observed due to stress relief, and subsidence. In the 1980s the SECV (State Electricity Commission Victoria) engaged global expert Don Helm to investigate observed subsidence. He concluded that it was being caused by aquifer pumping induced effective stress changes in thick and compressible clay and coal sediments (Helm 1987). Further, that there is a time lag between aquifer drawdown and changes in stress in these adjacent strata, delaying strata compression and any resultant surface subsidence.

From the start of mining at Hazelwood, pumping from deep aquifers was required to reduce floor heave and flooding risks. The effect of this pumping, when combined with other aquifer water users, has been to lower the pressure in two main regional aquifers: Morwell M1 (MFAS) and Morwell M2 (TFAS) (Figure 1). 


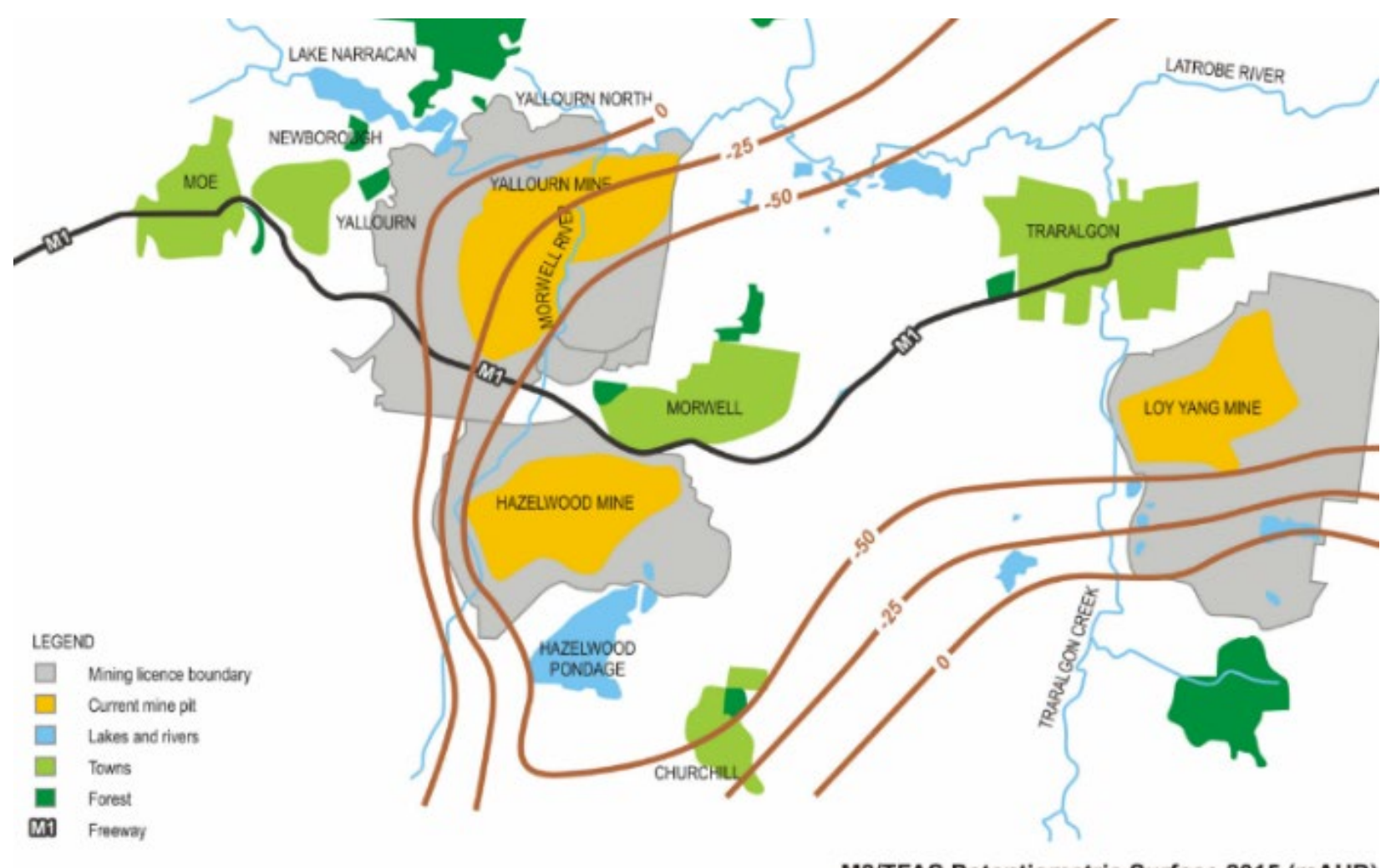

M2/TFAS Potentiometric Surface 2015 (mAHD)

Figure 1 M2 aquifer pressure in 2015 across the West Gippsland region

Over the past 60 or more years there has been gradual subsidence across the region of about 0.3 to $0.5 \mathrm{~m}$, increasing closer to the mines (Figure 2). Whilst land subsidence has been significant, it has occurred steadily and without differential subsidence, or impact to community infrastructure. A small rate of subsidence is occurring whilst pumping of 10-15 GLpa continues.

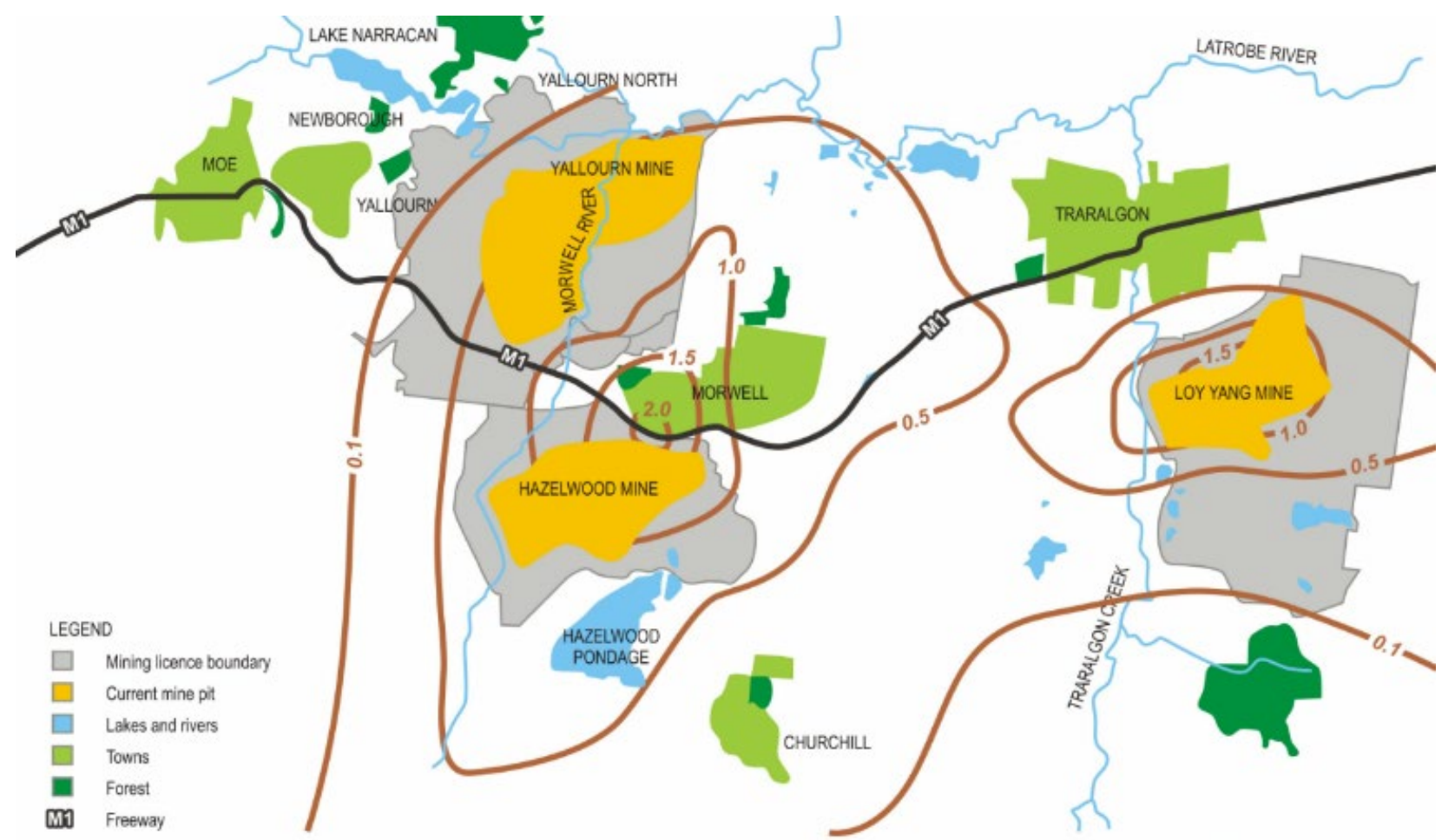

Regional Subsidence 1958-2015 (mAHD)

Figure 2 Subsidence between 1958-2015 across the West Gippsland region 
Figure 3 illustrates the relationship between subsidence and aquifer drawdown. Close to the mine the M2 aquifer drawdown has been in the order of $130 \mathrm{~m}$ and subsidence of about $150 \mathrm{~cm}$ has occurred. Further from the mine both drawdown and subsidence has been much smaller.

\section{Subsidence vs Drawdown 1960 to 2015}

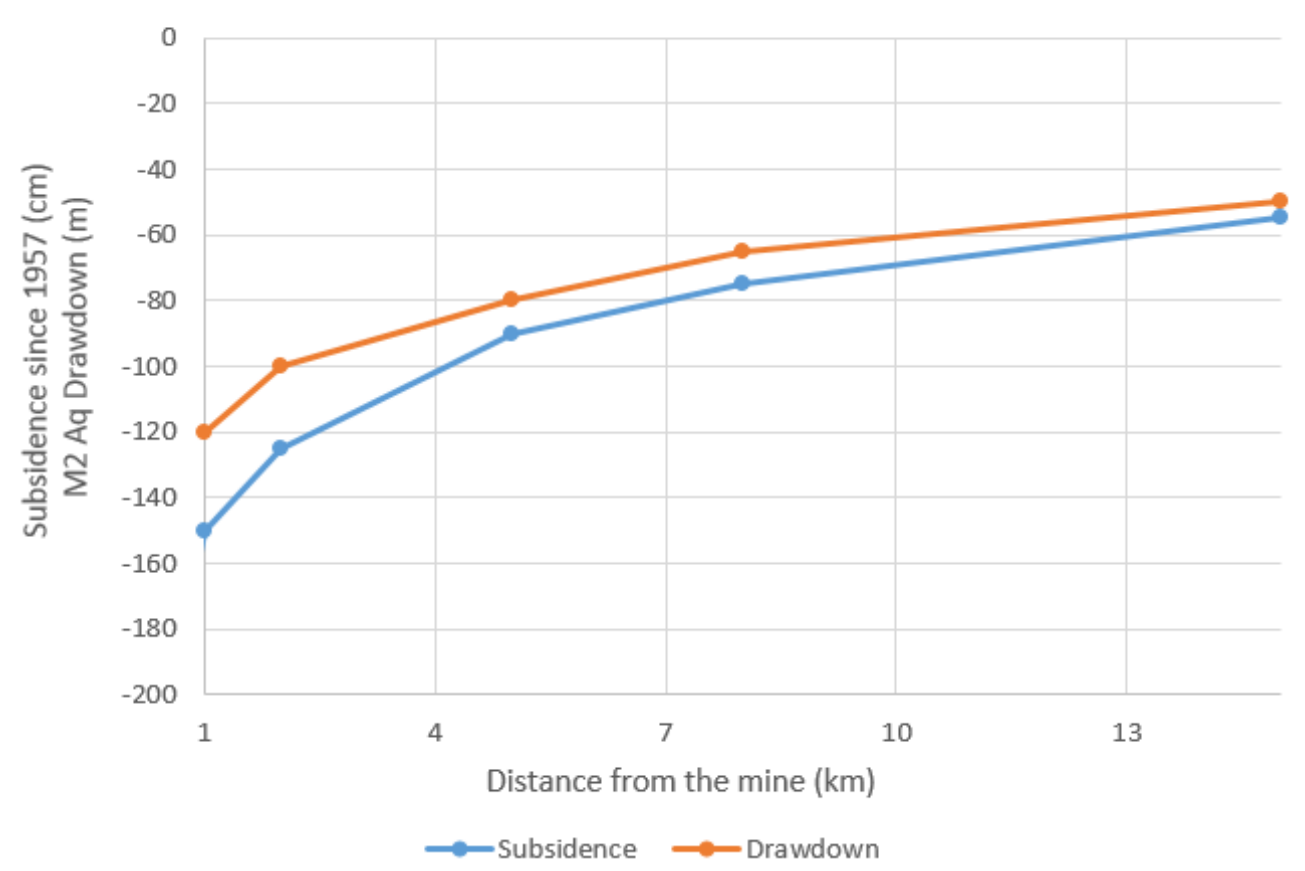

Figure 3 Relationship between subsidence and M2 aquifer drawdown

Most subsidence is due to compression of thick coal seams and interseam sediments that are adjacent to the aquifers (Table 1).

Table 1 Typical strata in a regional location showing main aquifers

\begin{tabular}{cc}
\hline Strata & Thickness (m) \\
\hline Oallourn Coal Seam & $20-30$ \\
Morwell M1 Coal Seam & $20-30$ \\
M1 Interseam and M1 Aquifer & $120-165$ \\
M2 Coal Seam & $10-20$ \\
M2 Interseam & $50-60$ \\
\hline & $50-150$ \\
\hline & \\
\hline
\end{tabular}

In the 1980s the SECV also carried out a deep drilling program across the Latrobe Valley. This enabled measurement of in situ pore pressures and testing of the overconsolidated strata. In bore M3067, as reported by Regan \& Ash (1986), in situ effective stress changes from 1960 to 1985 are shown on Figure 4 (dashed and part solid lines). Based on their work (and knowing the aquifer drawdown at the mine has been about $130 \mathrm{~m}$ ) an estimate of the in situ effective stresses to depth in 2015 has been added as a dashed red line. In the region, aquifer pumping induced pressure changes from 1960 levels will have been smaller. 


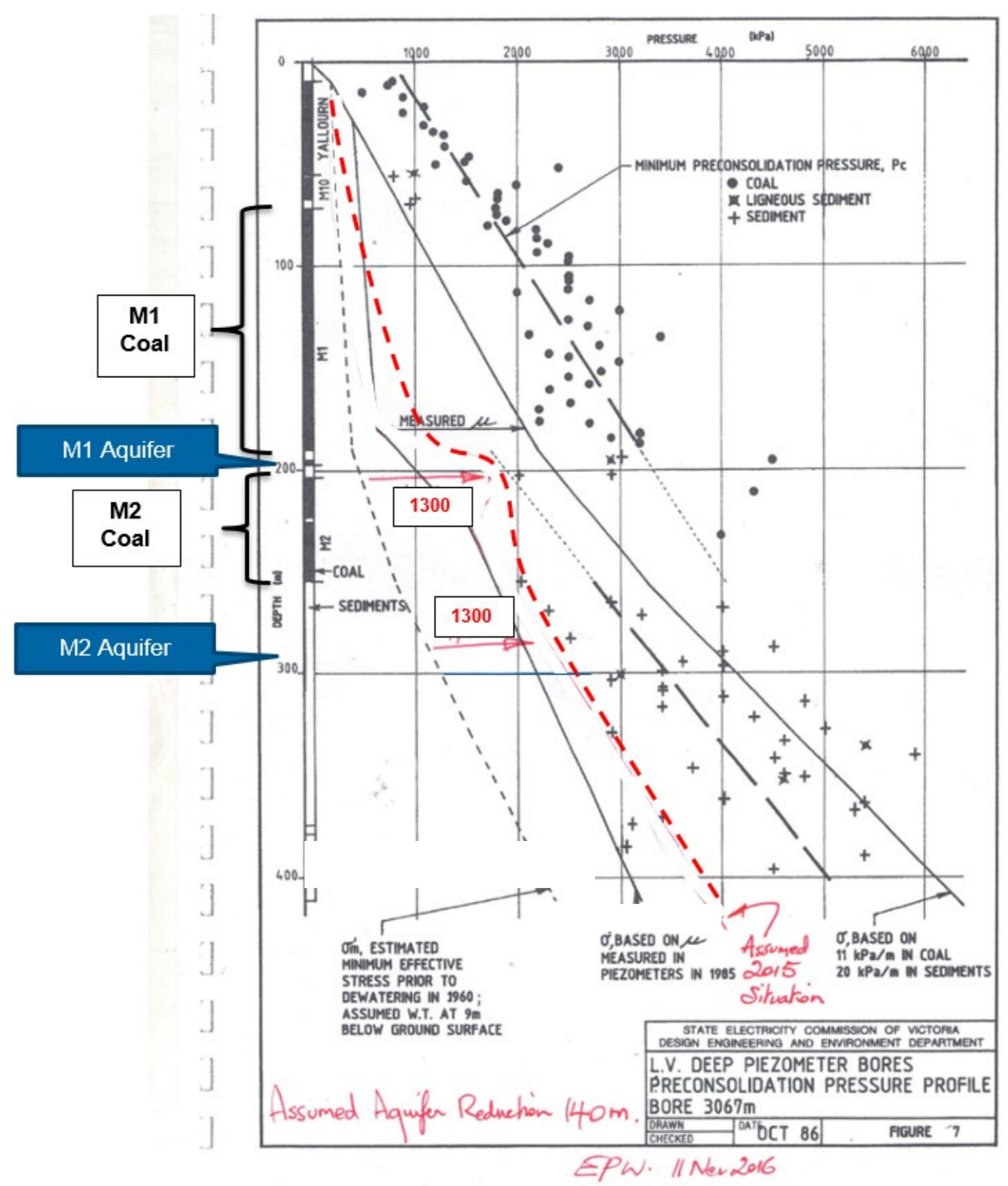

Figure 4 In situ effective stress changes at bore M3067 (based on Regan \& Ash 1986)

\section{Investigations to understand future changes to the land surface}

Planned mine rehabilitation at Hazelwood Mine includes a lake at about river level. This will provide sufficient weight to prevent mine floor instability, even after aquifer pressures fully recover following cessation of aquifer pumping. Aquifer pressures across the region are anticipated to only recover slowly whilst there is continued pumping by other extractors. It is anticipated that aquifer pressure recovery will take a further 50 , 100 or even more years, to stabilise at or near river levels.

As aquifer pressures recover, in situ effective stresses in strata adjacent to the aquifer sands will gradually reduce, slowing strata compression and land surface subsidence. Some land surface rebound is then expected to commence due to strata swelling.

Historically most consolidation testing of Latrobe Valley sediments has concentrated on the compressive properties of strata to assess land subsidence. In the future, with aquifer pressures rising, the swell properties of strata will be more relevant. Whilst some swell property data is available, additional tests of the thick compressible strata were funded by ENGIE.

Compression testing of bore core samples at the University of Melbourne (UoM). The tests were carried out in two stages. Stage 1 simulated increasing in situ effective stresses caused by aquifer pressure drawdown since the 1960s, and then a reduction of load simulating changes after aquifer pumping ceases. During 
Stage 1 the changing rate of compression is shown by tangential yellow and red lines (Figure 5). As the sample is unloaded some swelling occurs with increased void ratio (purple line). For Stage 2 further compression load was applied and then reduced with swell shown as the green line. The ratio of the amount of swell to compression has been determined for each stage (Figure 6).

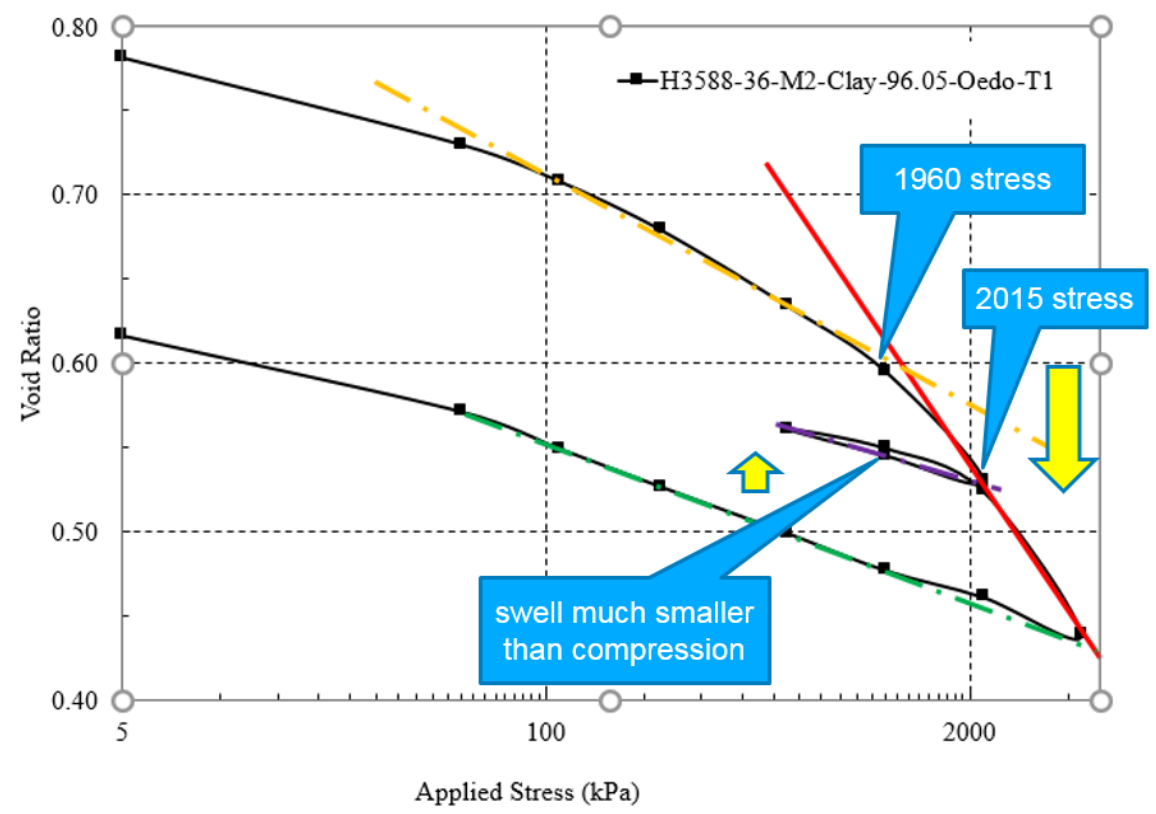

Figure 5 Oedometer test T1 of M2 interseam clay

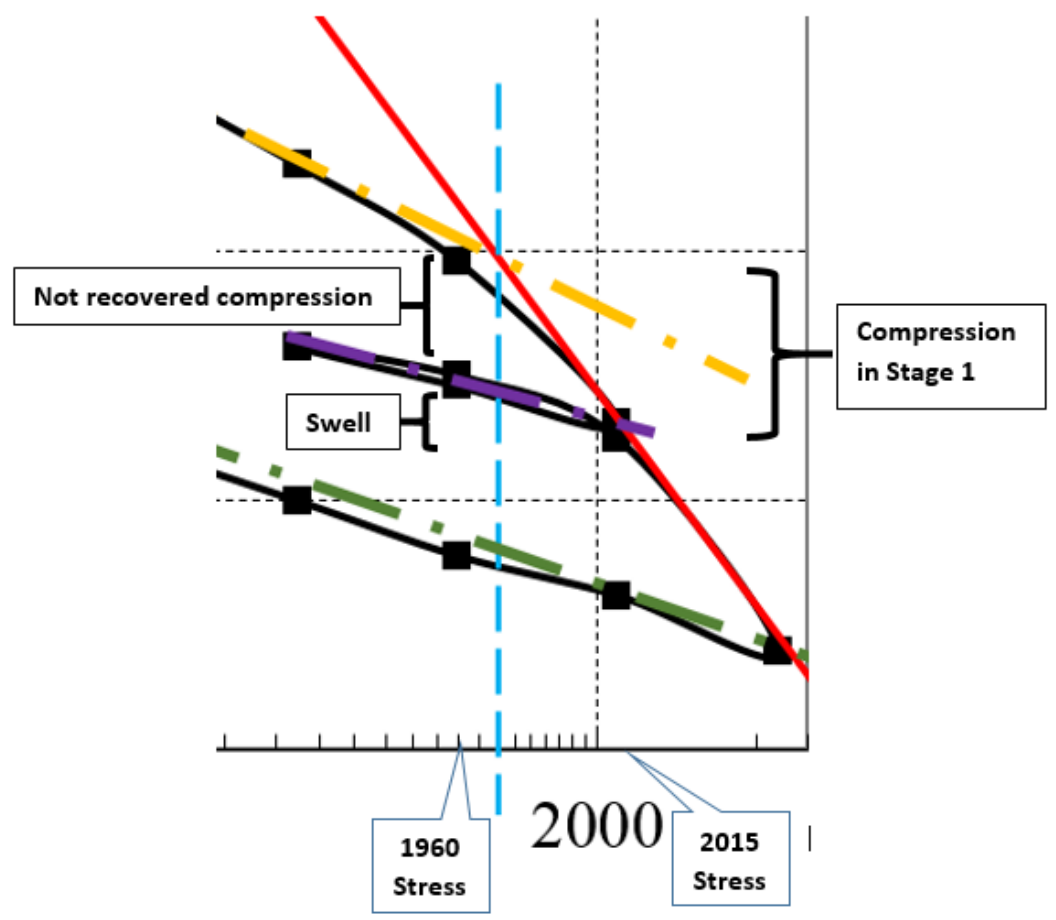

Figure 6 Detailed presentation of Oedometer test T1 at key stress levels

Whilst early soil mechanics theory suggests that below pre-consolidation stresses, soils could recover all of their compression by swelling (Poland \& Working Group 1984); more recent studies question this theory, suggesting a progressive reduction of elastic behaviour in fine-grained soils as stresses approach pre-consolidation levels (Giese 2010; Krupp 2015). Clay tests carried out as part of this program support these later theories with swell much smaller than compression. A number of coal tests were also carried out, with results shown on Figure 7. 


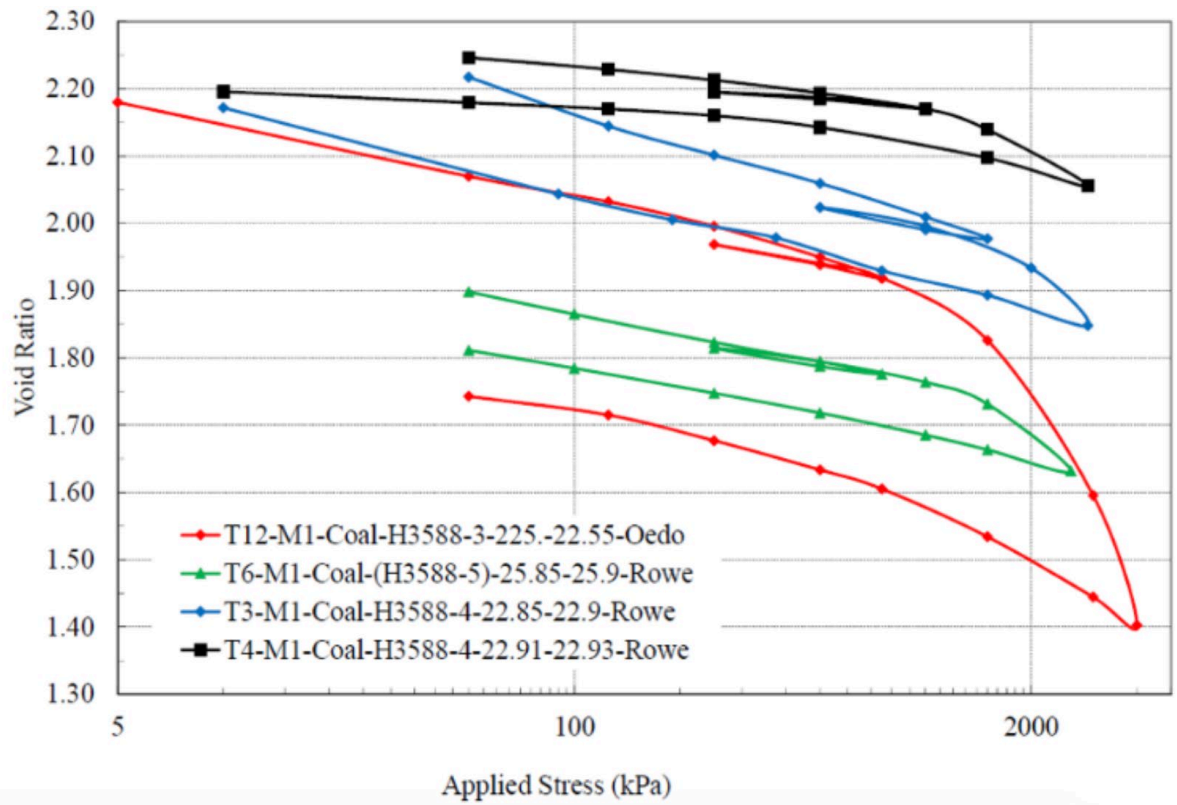

Figure 7 Compression/swell tests of M1 coal

Coal tests to simulate in situ stress changes indicated that the proportion of swell to compression reduces as the load level increases. Possible reasons for this are changes to the coal microstructure or to chemical bonding during loading that result in smaller swell properties. Further testing at the UoM by Tyagi \& Balkis (2018) show that the coal microstructure changes under load. Coal samples loaded to 2,500 kPa showed densification of the honeycomb voids that persisted after unloading of the sample (Figure 8 upper). This is characterised by a reduction in the diameter of the pores and an overall thickening in the pore walls leading to lower swell. Chemical bonding was also shown to change under load (Figure 8 lower): C13 NMR spectra before (a) and after (b) loading demonstrate an increase in the overall proportion of strong alkyle carbon bonds, and a reduction in weak carbonyl bonds.
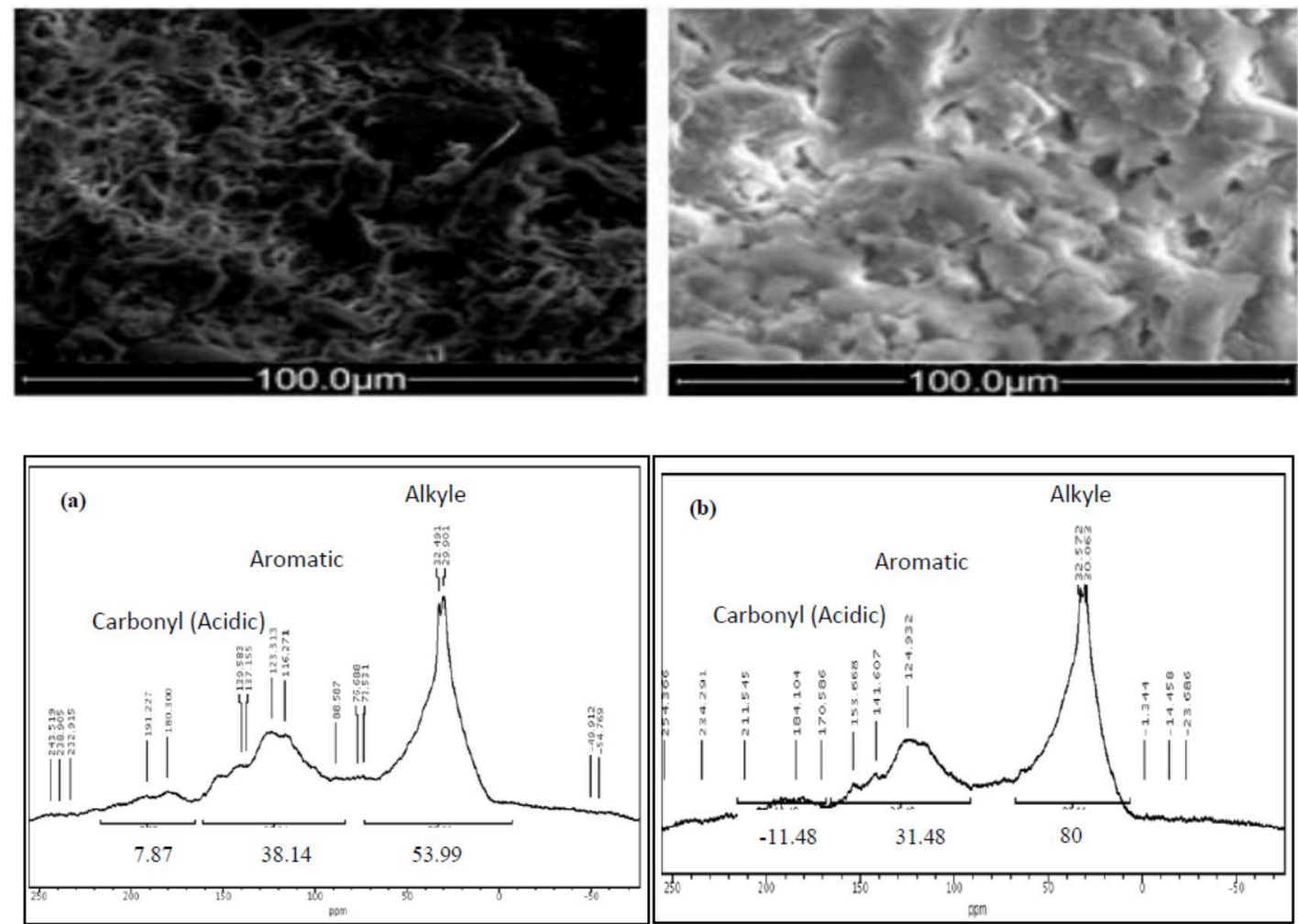

Figure 8 Observed changes in coal microstructure and chemical bonding (Tyagi \& Balkis 2018) 
A summary of the results of Stage 1 tests for each stratum show most swell/compression ratios are less than $50 \%$ (Table 2). Tests conducted at higher stresses expected near the mine are shown on the second last column. The swell/compression ratio for each stratum increases at lower stress levels expected in the region when lower aquifer drawdown has occurred (see last column).

Brown coal creeps, even under low compressive loads (Woskoboenko et al. 1991). Creep has been reported for peats that have many similar properties to brown coal (Mesri \& Stark 1997). More tests are planned, where loading is to be held for a longer time, to see if creep is recoverable and whether any changes to the swell properties of the coal occur.

\section{$3 \quad$ Future regional land surface movement}

Subsidence will continue whilst aquifer pressures are held at current levels. After mine rehabilitation and lake filling, aquifer pumping at the Hazelwood Mine is planned to stop. Aquifer pressures are expected to slowly rise (Figure 9).

Table 2 Summary of Stage 1 tests - swell/compression

\begin{tabular}{|c|c|c|c|c|c|}
\hline \multicolumn{6}{|c|}{ University of Melbourne - 2017 and 2018 Stage 1 consolidation test results } \\
\hline \multirow[b]{2}{*}{ Material type } & \multirow[b]{2}{*}{ Test } & \multirow[b]{2}{*}{ Test method } & \multirow[b]{2}{*}{ Stage 1 test $\mathrm{kPa}$} & \multicolumn{2}{|c|}{ Swell/compression } \\
\hline & & & & Near mine* & Regionalt+ \\
\hline M1 Coal & RT3 & Rowe cell & 1,500 & $44 \%$ & \\
\hline M1 Coal & $\mathrm{RT}^{\wedge}{ }^{\wedge}$ & Rowe cell & 1,000 & $59 \%$ & \\
\hline M1 Coal & RT6 & Rowe cell & 750 & & $56 \%$ \\
\hline \multirow[t]{2}{*}{ M1 Coal } & OT12 & Oedometer & 750 & & $65 \%$ \\
\hline & & & Average & $51 \%$ & $61 \%$ \\
\hline M1 Clay & RT2 & Rowe cell & 1,500 & $27 \%$ & \\
\hline M1 Clay & RT7 & Rowe cell & 750 & & $43 \%$ \\
\hline M1 Clay & OT5 & Oedometer & 1,500 & $48 \%$ & \\
\hline M1 Clay & OT6 & Oedometer & 1,500 & $21 \%$ & \\
\hline \multirow[t]{2}{*}{ M1 Clay } & OT13 & Oedometer & 900 & & $43 \%$ \\
\hline & & & Average & $32 \%$ & $43 \%$ \\
\hline M2 Coal & ОТ9 & Oedometer & 1,000 & & $39 \%$ \\
\hline M2 Coal & От10 & Oedometer & 750 & & $42 \%$ \\
\hline \multirow[t]{2}{*}{ M2 Coal } & ОT10 & Oedometer & 1,800 & $38 \%$ & \\
\hline & & & Average & $38 \%$ & $41 \%$ \\
\hline M2 Clay & RT1 & Rowe cell & 2,900 & $23 \%$ & \\
\hline M2 Clay & RT5 & Rowe cell & 2,200 & $25 \%$ & \\
\hline M2 Clay & OT1 & Oedometer & 2,200 & $23 \%$ & \\
\hline M2 Clay & От2^ & Oedometer & 2,200 & NA & \\
\hline M2 Clay & ОТ3^ & Oedometer & 2,200 & NA & \\
\hline M2 Clay & OT4 & Oedometer & 2,200 & $24 \%$ & \\
\hline M2 Clay & OT7^ & Oedometer & 2,200 & $48 \%$ & \\
\hline M2 Clay & от8\# & Oedometer & 1,100 & & $64 \%$ \\
\hline \multirow[t]{2}{*}{ M2 Clay } & OT11 & Oedometer & 2,200 & $43 \%$ & \\
\hline & & & Average & $31 \%$ & $64 \%$ \\
\hline
\end{tabular}

* - Test at predicted in situ stresses near the mine; +- Test at lower pressures found in a more regional location;

$\wedge$ - Test issues; \#- Much lower applied stress than predicted in situ stress. 


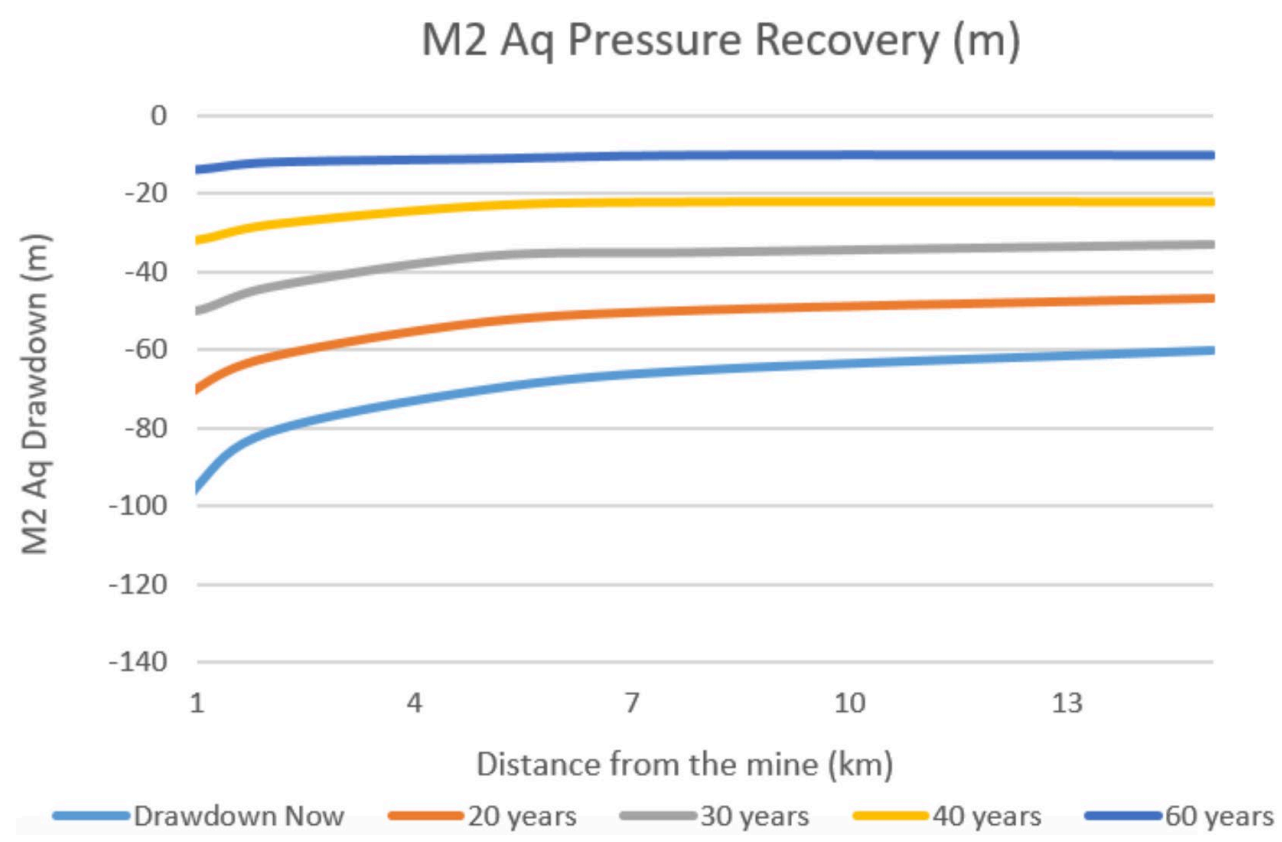

Figure 9 Possible M2 aquifer recovery after pumping ceases

Across the region, rising aquifer pressures will gradually increase pore pressures in thick coal and clay strata. The speed of this change will depend mainly on the permeability of aquitards and the compressible strata. The resultant reduced in situ stresses will allow swelling of the strata, causing land surface rebound.

Recognising that there has been limited testing; the results have been applied to appreciate long-term ground movements around the Hazelwood mine. For this initial assessment a number of assumptions have been made including site geology, current and future stress levels, strata swell/compressible ratios and non-recoverable creep. Values used in the analysis are shown on Table 3.

Table 3 Key swell/compression and creep values used in rebound analysis

\begin{tabular}{lcc}
\hline Strata & $\begin{array}{c}\text { Swell/compression } \\
\text { ratio }\end{array}$ & $\begin{array}{c}\text { Non-recoverable } \\
\text { creep }\end{array}$ \\
\hline Coal & $50-60 \%$ & $25-20 \%$ \\
M1 Clay & $30-45 \%$ & $10-5 \%$ \\
M2 Coal & $30-40 \%$ & $30-20 \%$ \\
M2 Clay & $25-50 \%$ & $15-10 \%$ \\
\hline
\end{tabular}

Assumed swell/compression ratios decrease with depth and increase further from the mine. Assumed non recoverable creep increases with depth and reduces further from the mine.

Using strata compression based on Helm (1987), the potential long-term land surface rebound at two typical regional locations about 15 and $5 \mathrm{~km}$ from the mine is estimated on Table 4.

This analysis indicates there is potential for land surface rebound of $25-40 \%$ of the subsidence that has occurred since 1960 (Figure 10). However, due to the time it will take for pore pressures to stabilise and the uniformity of local geology the rebound is expected to only occur slowly over the next 100 years and is unlikely to have any noticeable impact on community infrastructure. 


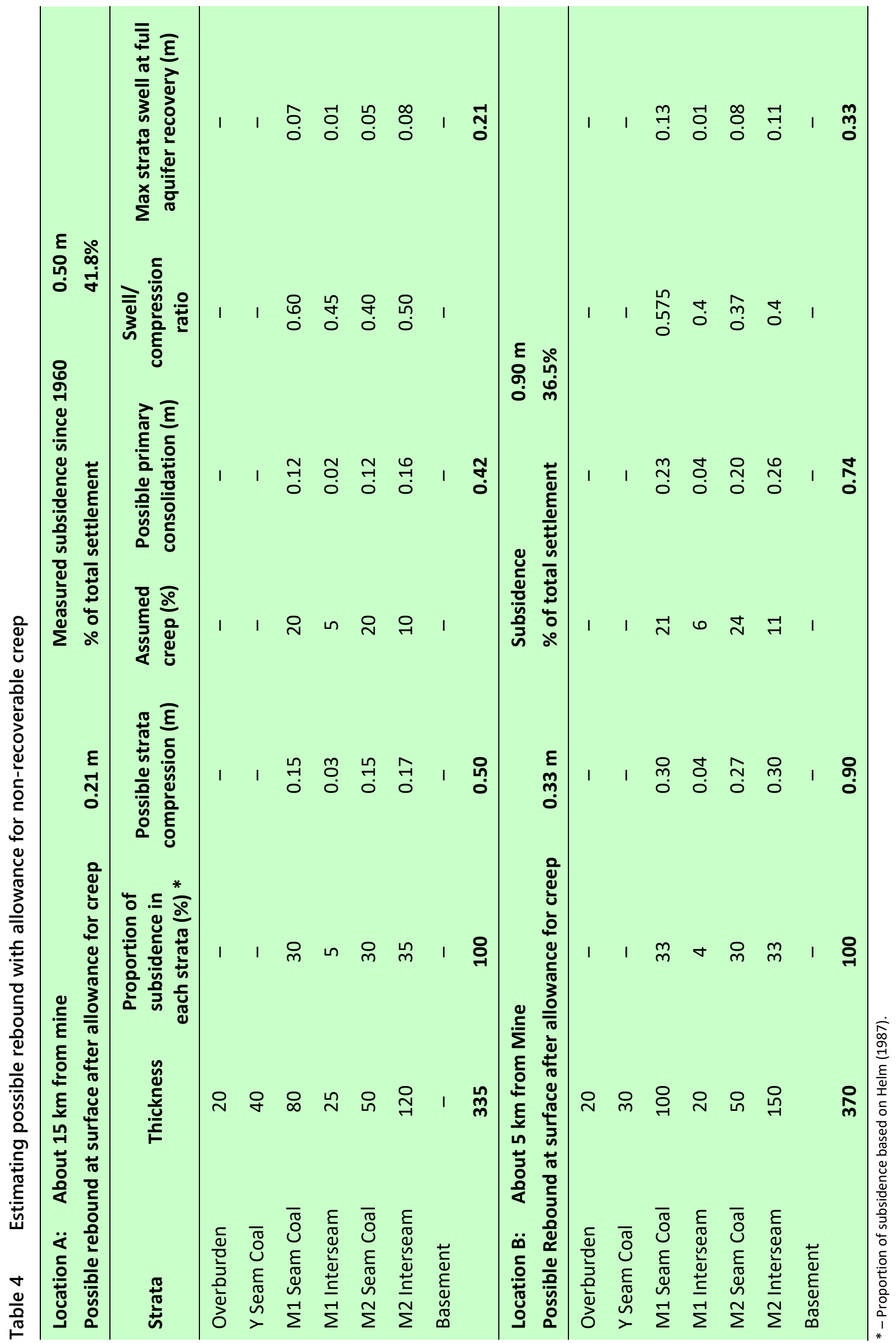




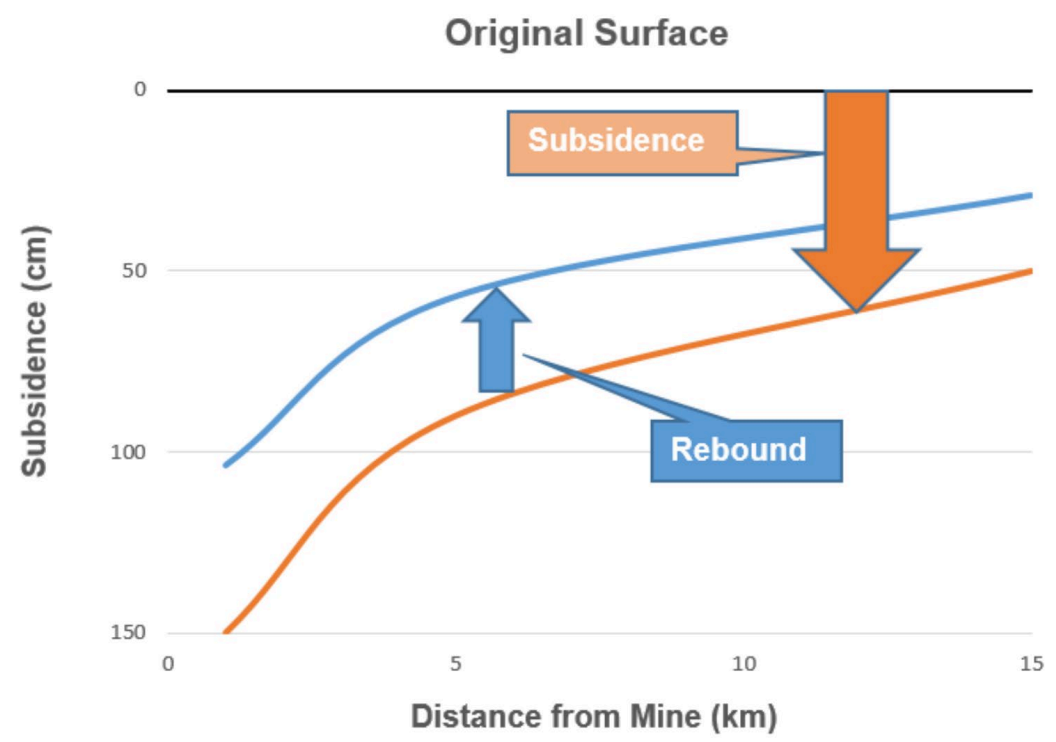

Figure 10 Measured subsidence and possible regional land surface rebound

Further work is planned with the continued support of ENGIE in the development of their Rehabilitation and Closure Plan for the Hazelwood Mine to:

- Refine the prediction of aquifer pressures in 2050 and 2100, based on assumed mine closure dates and aquifer pumping reductions.

- Carry out additional compression and swell strata testing including assessing the effect of creep in coal.

- Investigate microstructure changes within coal samples during compression that could affect (reduce) swell behaviour.

- Apply the 1D COMPAC model to predict surface movements at a number of key points across the Latrobe Valley.

- Incorporate findings into SUBS 3D regional modelling to show regional progressive changes to the natural surface over the next 100 or so years.

\section{Acknowledgement}

The authors would like to thank ENGIE for permission to prepare this paper; also Technical Services Manager, James Faithful, for his review and contribution to this report and Mine Geologist, Matt Holmes, for his work in obtaining the necessary samples for testing. At the University of Melbourne thanks are also due to Amir Mehdizadeh for material compression and swell testing; and to Lakshya Tyagi and Jacques Balkis for their capstone research project on the changing microstructure and chemical bonding in coal.

\section{References}

Giese, S 2010, Ground Movement Causing Regional Settlement as can be Seen in the Vicinity of Deep Open Cuts in the Rheinish Brown Coal Area, PhD thesis, Rheinisch-Westfälische Technische Hochschule Aachen University, Aachen.

Helm, D 1987, 'Prediction of subsidence due to groundwater withdrawal in the Latrobe Valley, Australia', Proceedings of the Sixth International Congress on Rock Mechanics, vol. 1, CRC Press, London.

Krupp, RE 2015, Effects of Groundwater Conservation in the Rhineland Brown Coal Area on the Topography and the Groundwater Levels, and Consequences for Buildings, Agricultural Land, Infrastructure and the Environment, study commissioned by Alliance 90 for The Greens in the Parliament of North Rhein Westphalia, Germany, $138 \mathrm{p}$.

Mesri, G \& Stark, TD 1997, 'Secondary compression of peat with or without surcharging', Journal of Geotechnical and Geoengineering, May.

Poland, JF \& Working Group 1984, 'Mechanics of land subsidence due to fluid withdrawal', in JF Poland (ed.), Guidebook to Studies of Land Subsidence Due to Ground-water Withdrawal, UNESCO, Paris. 
Regan, WM \& Ash, PJ 1986, 'Latrobe Valley deep piezometer bores 2996M and 3067M, laboratory test results', SECV Design Engineering and Environment Department Report No. GDD6.

Tyagi, L \& Balkis, J 2018, 'Impact of chemical bonding and microstructure on the rebound behaviour of brown coal during stress-relief', research paper, Department of Infrastructure Engineering, University of Melbourne, Melbourne.

Waghorne, EP 2009, 'Brown coal mining in the Latrobe Valley', Monograph 12 Australasian Coal Mine Practice, 3rd edn, The Australasian Institute of Mining and Metallurgy, Carlton, pp. 470-485.

Woskoboenko, F, Stacy, WO \& Raisbeck, D 1991, 'Physical structure and properties of brown coal', in RA Durie (ed.), The Science of Victorian Brown Coal: Structure, Properties and Consequences for Utilization, Commonwealth Scientific and Industrial Research Organisation, North Ryde, pp. 152-245. 
